\title{
Taxonomic diversity of macroflora vegetation among main stands of the forest of Wanagama I, Gunung Kidul
}

\author{
WIDODO $^{1, \varphi}$, SUTARNO $^{2}$, SRI WIDORETNO ${ }^{3}$, SUGIYARTO $^{2, \text { }}$ \\ ${ }^{1}$ Faculty of Science and Technology, State Islamic University (UIN) Sunan Kalijaga, Jl. Marsda Adisucipto No. 1, Yogyakarta 55281, Indonesia, Tel. \\ +62-274-519739, Fax. +62-274-540971, `email: widodolsumarno@ rocketmail.com 2 \\ ${ }^{2}$ Department of Biology, Faculty of Mathematics and Natural Sciences, Sebelas Maret University (UNS), Jl. Ir. Sutami 36A, Surakarta 57126, Central \\ Java, Indonesia, Tel. \& Fax.: +62-271-663375, "wemail: sugiyarto_ys@yahoo.com 3 \\ ${ }^{3}$ Biology Program, Faculty of Education and Pedagogic, Sebelas Maret University (UNS), Jl. Ir. Sutami 36A, Surakarta 57126, Central Java, Indonesia
}

Manuscript received: 29 March 2009. Revision accepted: 28 September 2009.

\begin{abstract}
Widodo, Sutarno, Widoretno S, Sugiyarto (2010) Taxonomic diversity of macroflora vegetation among main stands of the forest of Wanagama I, Gunung Kidul. Biodiversitas 11: 89-92. The objective of this study is to determine the diversity of taxonomy of macro flora vegetation in the main stands of the forest of Wanagama I in Gunung Kidul, Yogyakarta, Indonesia. Vegetation diversity data can be used as a recommendation for conserving the local biodiversity as well as other planned conservation activities. The nested square sampling method was applied to collect the data required in the research. The size of the nested square was based on species-area curves, as well as theories of other studies. The seven main stands studied were: pine (Pinus merkusii), mahogany (Swietenia mahagoni), kesambi (Schleichera oleosa), teak (Tectona grandis), cajuput (Melaleuca leucadendron), Gliricidia (Gliricidia sepium), and a mixed stand. Each stand was observed four times. The square location was randomly determined based on a contour map of the area. The variables of the study of diversity in terms of taxonomy consist of species, genus, family, and order richness. The results were, then, analyzed statistically using one-way Analysis of Variance (ANOVA) and Turkey's test. The result of the study shows that the species of the main stands was affected very significantly by the diversity of all level: species, genus, family, and order total richness. The Pine stand has the highest rank in terms of number of species, genus, family, and order richness.
\end{abstract}

Key words: taxonomic diversity, main stands, Wanagama.

\section{INTRODUCTION}

The lost of our biological diversity in the forms of genetic erosion and species extinction is the very fundamental problem that should be addressed immediately. Basically, there are two types of conservation strategy; in-situ and ex-situ (Primack et al. 1998). The forest of Wanagama I in Gunung Kidul, Yogyakarta is a representative sample of ex-situ conservation of plants and genetic diversity (Fakultas Kehutanan UGM 2001). This artificial forest functions as conservation area of local and endemic plants of Gunung Kidul. This role is important for reducing human's negative influences towards the nature, habitats, and wild species.

The conservation efforts -whether in a big scale or a small scale- always need the data of species diversity. Nowadays, at least 1.4-1.8 million species of 30 million predicted species have been named (Soeriaatmadja 2000). There are discontents related to data inadequacy about forest organism from many researchers (Groombridge 1992; Whitmore and Sayer 1994). Biodiversity conservation and development requires a clear measurement database. IUCN/UNC/ WWF notes that in various extinction cases the measurement of losing genetic potentials is related to the hierarchy of taxonomy, because the differences in terms of position within the hierarchy reflects the size of genetic differences (Groombridge 1992). Measuring diversity that has now been recommended is measuring genetic variation by using the hierarchy directly or indirectly. According to many scientists, the indirect ways are more practical, because the hierarchy is an easily observable measurement. Conducting biodiversity measurement of a conservation area is important to asses whether the conservation process succeeds or fails. Reports on the studies of the pattern of taxonomy of forest vegetation by counting the number of genus, family, order and other high taxa have been conducted by Foster and Hubbell (1986), Beaman and Beaman (1990), Sukristijono (1990), and Sohmer (1990).

Taxon species is most often applied as the foundation of evaluating and analyzing organism distribution. In this case, the higher level of taxon like genus and family is required. The methods of measuring biodiversity that have now been developed also considers some genetic differences of species at its relative position vis a vis other taxa within the classification hierarchy. Vane-Wright (1992a,b) is a pioneer in measuring the diversity which is based on cladistic hypothetic information (evolutive ramification patterns) as a measurement of taxonomic difference. Bibby et al. (1992) applied a simple method of recognizing taxonomic uniqueness to endemic species based on diversity of genus and family, in addition to species diversity. Those various methods are important 
applied to plant conservation. Identifying a conservation area requires such steps. Planning and organizing a conservation process also needs to conserve various populations in order to reduce organism extinction in an area (Groombridge 1992). The importance of taxonomic status in an evaluation process of species scarcity or ecology studies has long been addressed and conducted by Foster and Hubbell (1986).

\section{MATERIALS AND METHODS}

\section{Place and time of the field research}

The research has been conducted in the forest of Wanagama I, in Playen and Patuk sub-districts, Gunung Kidul district, Yogyakarta, Indonesia, from October 2002 to July 2003. Wanagama I consists of an area of 600 hectares divided into 8 main fields in which each has approximately 70 hectares. Some of the forest functions are as a conservation area of plant germplasm, especially trees. The functions are as tree recovery development; as a forest pioneer in terms of industrial plants; as multipurpose tree species, agroforestry development and so on.

\section{Materials}

The tools have been used to take the samples from the field consist of roll meter to determine the distance and plot wide. Plastic bags and vasculums were used as temporary containers of various unidentified plants. Other equipments were field testers, hatchets, scythes, knifes, scissors, pinsets, stationary, field books, compass, and a binocular. Label, newsprint paper, plant press, and type were used to make herbarium from unknown species. A hand counter was to count the number of individuals, while flags were used to mark the plots' size. The data obtained were, then, consulted to books to identify species and taxon hierarchy determination.

\section{Methods \\ Sampling methods}

Firstly, a field orientation was conducted by the help of a location map and by getting information from the forest officials. The observation areas include some plots or subplots in which the vegetations underneath were allowed to live naturally. The main stands were treated as independent variables. The wide of the main stands, numbers and types of species, family, class, macro flora vegetation underneath the forest were the dependent variables. The field of each stand having been determined as places of observation was functioned as observation stations and was used as main stand sampling and vegetation underneath the forest integrally by the method of nested quadrate double model (Soegianto 1994). The minimal plot size was based on area-species curves. The procedures refer to Sunarto (1991) and Barbour (1987). Each observation plot sizes $16 \times 16 \mathrm{~m}^{2}$ in the case of main stands, $8 \times 8 \mathrm{~m}^{2}$ in the case of shrubs; and $4 \times 4 \mathrm{~m}^{2}$ in the case of herbal plants, seedlings, and saplings (Figure 1). The scheme is visualized as follows:

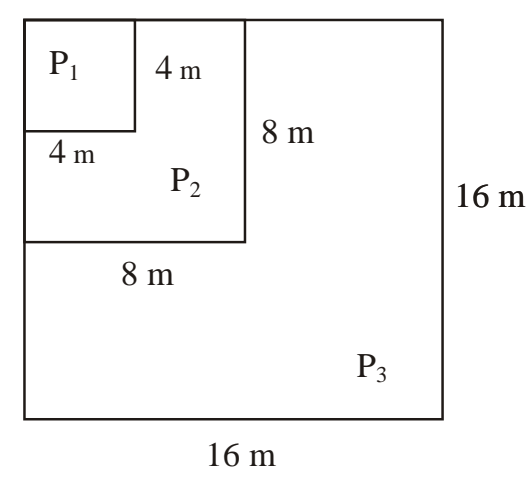

Figure 1. A nested-quadrat plot (Soegianto 1994).

The determination of plot locations was conducted systematically to minimize bias by considering the detail of the stands. There were a process of identifying and detailed-counting of individuals, life forms and the breasthigh diameter of trees and every plant in the plots.

Observation, identification and preservation of the specimens in the laboratory

The sample of plants or specimens which had not been recognized in the field were, then, identified in the laboratory by matching them to some literatures, such as Valeton (1918), Kooders (1924a,b), Meril (1949), Steenis (1954), Backer (1924, 1973), Soedarsono and Rifai (1975), Samingan (1982), Soerjani (1987), Battacarya (1992), Tjitrosoepomo (1994), and Soeryowinoto (1997).

\section{Vegetation analyses}

Taxonomic diversity of inter-area stands was determined for species, genus, family class taxonomic category and possibly those from higher levels. Taxon diversity was counted based on a number of particular taxon (species, genus, family, order and so on) or taxonomic richness. The method refers to Foster and Hubbell (1986), Beaman and Beaman (1990), Sohmer (1990).

\section{Data analyses}

Data from every parameter was analyzed statistically using Analyses of Variance (ANOVA) to determine whether there was any influence from particular stands on every dependent variable. The differences in terms of influences and response sequences by independent variable were discovered by Turkey's test to find out whether the result has any meaning (Subali 1990; Gaspersz 1991; Fry 1996)

\section{RESULTS AND DISCUSSION}

\section{Species taxon}

The types of the main stands had an influence on the number of plant species within the whole vegetation of the forest (Table 1). As the forest of Wanagama $I$ is a secondary conservation forest, the result shows that the types of stand species for the pioneer of forest vegetation would consequently determine the numbers of species that 
would live within. Every plant or tree species which has become the stands has particular characters of morphology, physiology, and biochemistry. Those characters have two kinds of influences; on physico-chemistry environment and on biotic environment. The physico-chemistry environment consists of soil stone structure, soil erosion, the structure of soil texture, nutrient types and component of soil, soil similarity, soil humidity, light intensity, and other microclimate components. The biotic environment consists of microflora and microfauna richness, flora and fauna distribution. According to Polunin (1990), plants (vegetations) have particular influences on various types of soil changes and other plants (allogenic influence). The existence of certain species would influence the presence or the absence of other species.

The fact resulted from the research supports an assumption that there was a species richness variation within a local variation. It is very well supported by Kohyama (1997) that spatial heterogeneity of vegetation is a resultant of micro resources and environment which then forms vegetation architectures, including the compiler species (Table 1). Pine stands contain the highest number of species, while Gliricidia stands have the lowest one. Pine stands have a canopy structure which enables light to reach the soil, hence it is possible for other plants to grow, i.e. trees, shrubs, and herbs. On the contrary, Gliricidia stands have a canopy structure that enables only a part of light to reach the soil. Consequently, these kinds of stands have the lowest species richness. The ability of high dispersal and density of sapling in the form of blush and clamp at the main stands is assumed to have been the cause of the shortage of other species.

\section{Genus taxon}

The number of genus among the stands also shows some differences. It means that there was an influence of the types of stands on the vegetation profile of the forest as a whole (Table 1). Pine stands have the highest number of genus diversity. Statistical evidence confirms that the pine stands were different significantly to other stands. Gliricidia stands have the lowest genus diversity compared to other stands. Mahogany, kesambi and mixed stands show indifferent genus diversity. While teak stands were similar to cajuput stands.

Generally, plant species found in the field are heterogeneous, consisting of various genera. Only some of them are from the same genus, for instance salam and jambu air. They are the members of Eugenia genus and

Table 1. Average number of macroflora taxon (species, genus, family, order) between stands in Wanagama I.

\begin{tabular}{lrrrrrrr}
\hline \multirow{2}{*}{ Taxon } & \multicolumn{7}{c}{ Stands } \\
\cline { 2 - 7 } & \multicolumn{1}{c}{ Pine } & Mahogany & Kesambi & Teak & Cajuput & Glerecidae & Mix \\
\hline Species & $33.25^{\mathrm{a}}$ & $22.25^{\mathrm{b}}$ & $23.50^{\mathrm{b}}$ & $17.00^{\mathrm{bc}}$ & $21.00^{\mathrm{bc}}$ & $14.50^{\mathrm{c}}$ & $23.50^{\mathrm{b}}$ \\
Genus & $33.00^{\mathrm{a}}$ & $22.25^{\mathrm{b}}$ & $21.00^{\mathrm{b}}$ & $16.50^{\mathrm{bc}}$ & $18.25^{\mathrm{bc}}$ & $14.00^{\mathrm{c}}$ & $22.75^{\mathrm{b}}$ \\
Family & $22.00^{\mathrm{a}}$ & $16.25^{\mathrm{b}}$ & $17.25^{\mathrm{b}}$ & $14.00^{\mathrm{bc}}$ & $14.00^{\mathrm{bc}}$ & $11.50^{\mathrm{c}}$ & $17.25^{\mathrm{b}}$ \\
Order & $17.25^{\mathrm{a}}$ & $10.75^{\mathrm{b}}$ & $14.50^{\mathrm{b}}$ & $12.25^{\mathrm{bc}}$ & $11.75^{\mathrm{bc}}$ & $9.25^{\mathrm{c}}$ & $10.75^{\mathrm{b}}$ \\
\hline
\end{tabular}

Information: the same letter from the same line shows that there is no real different at Turkey's test. $\alpha=0.05$. from acacia type. This makes the data of the number of genus between stands is relatively same as the data of the number of species. Between plants in a genus, the morphological character was relatively similar, although there were many species in a genus. Foster and Hubbell (1986) stated that species diversity is parallel to genus diversity in a natural forest. Stuessy et al. (1998) counted the number of flowering plants in Juan Fernadez Island and found that there were 73 families, 234 genus, 383 species. From this study, it is understood that the number of the genus is similar to the number of species.

\section{Family taxon}

This study shows that the number of family found in the stands influences the number of family of the forest vegetation as a whole (Table 1). As the data confirmed, the pine stands have the highest number of family diversity, while the Gliricidia stands have the lowest one. This fact is due to a big number of families found in the forest is monogeneric (consists of only one genus or one species). As a consequence, the number of family diversity is parallel to the number of the genus and species diversity.

From the conservation perspective, the pine has the highest potential of genetic conservation because they contain a relatively high number of species, genus, and family diversity. In addition, the patterns of family, genus, and species diversity in the stands are similar to those of the whole forest because Wanagama I is a secondary forest. As a secondary forest, some stands are actually introduced by species brought from other areas and even other continents. Human influences on the forest are a significant factor that determines the dynamics of the forest community, although these influences had begun since a long time ago.

\section{Order taxon}

The type of stands influences the number of order diversity in the forest (Table 1). The pine stand contains the highest number of order diversity, while the Gliricidia has the lowest one. The mahogany, teak, cajuput, and mixed stands have the similar number of order diversity. Kesambi stand was in the second after the pine stand. The statistics confirms that the kesambi stand was significantly different to any other stands.

The result of this study shows that the type of main stands influences the size/ the diversity/ the density of vegetations in the level of species, genus, family, and order. As a comparison, Foster and Hubbell (1986) found that high level of taxonomy, such as family is not parallel with species and genus. The presence of taxon (species, genus, family, order) in an area is related to abiotic components of the environment, like precipitation rate, humidity, daily and seasonal temperature changes, and elevation (Stuessy 1990). Geological characteristics may also influence the distribution of a taxon. In 
addition, the biotic factors contribute to the dynamics of the organisms living in the area. In general, Stuessy et al. (1998) describes factors that determine the proportion of taxon in an area. Those are: spatial (geographic) factors, environmental (ecologic) factors, internal reproductive factors (incompatibility, hybrid problems), and external reproductive factors (temporal/phenologic factors and mechanism of reproduction factors, e.g. flower structures and autogamy).

\section{CONCLUSIONS AND SUGGESTIONS}

The number of species, genus, family and order of macroflora vegetation within the forest of Wanagama I, was affected by the types of the main stands. The Pine stands have the highest number compared to any other main stands. The fields within the forest should be used as sources of germplasm or genetic variation of local and wild plants by means of allowing them to live (without intensive cutting and so on). It requires further research to discover the benefits of genetic advantages owned by the wild plants, especially from the group of local shrubs, local clumps and local trees exploratively.

\section{REFERENCES}

Backer CA (1924) Exkursions flora von Java. Verlag von Gustav Fischer, Jena.

Backer CA (1973) Weed flora of Javanese sugar cane fields. vol. 7. atlas. Ysel Press, Deventer.

Barbour MG (1987) Terrestrial plant ecology. Benjamin Cummings, Singapore.

Battacarya B (1992) Taxonomy of flowering plant. Benjamin Cummings, New Delhi.

Beaman JH, Beaman RS (1990) Diversity and distribution patterns in the flora of Mount Kinabalu. In Baas P (ed) The plant diversity of Malesia. Kluwer, Dordrecht.

Bibby JC, Crosby MJ, Heath MF, Johnson TH, Long AJ, Stattersfield AJ Thirgood SJ (1992) Putting biodiversity on the map: global priorities for conservation. ICBP, Cambridge.

Fakultas Kehutanan UGM (2001) Peringatan 35 tahun hutan Wanagama I. Fakultas Kehutanan UGM, Yogyakarta.

Foster RB, Hubbell S (1986) Commonest and rarity in Neotropical forest: implications for tropical trees conservation. In: Soule ME (ed) Conservation biology, the science of scarcity and diversity. Sinaeur, Massachusetts.
Fry JC (1996) Biological data analysis, a practical approach. Oxford University Press, Oxford.

Gaspersz V (1991) Metode perancangan percobaan untuk ilmu-ilmu pertanian, teknik, biologi. Armico, Bandung.

Groombridge B (1992) Global biodiversity, status of earth's living resources. Chapman and Hall, London.

Kohyama T (1997) The Role of Architecture in Enhancing Plant Species Diversity. In: Higashi M (ed) Biodiversity. Springer, New York.

Kooders SH ( 1924a) Exkursionsflora von Java. Alias 4. Ableilung: I. Halfle: Familie 50. Verlag von Gustav Fischer, Jena.

Kooders SH (1924b) Exkursionsflora von Java. Alias 4. Ableilung. 2. Halfte: Familie 50. Verlag von Gustav Fischer, Jena.

Polunin N (1990) Pengantar geografi tumbuhan. Gadjah Mada University Press, Yogyakarta.

Primack RB, Indrawan M, Prayitno B (1998) Biology konservasi. Gadjah Mada University Press, Yogyakarta.

Samingan T (1982) Dendrologi. Gramedia, Jakarta.

Soedarsono A, Rifai MA (1975) 50 Gulma di perkebunan. Balai Pustaka, Jakarta.

Soegianto A (1994) Ekologi kuantitatif. Usaha Nasional, Surabaya.

Soeriaatmadja RE (2000) Pelestarian keanekaragaman hayati pulau Jawa dan Bali. Dalam: Setyawan AD, Sutarno (ed) Menuju Taman Nasional Gunung Lawu; prosiding semiloka nasional konservasi biodiversitas untuk perlindungan dan penyelamatan plasma nutfah di pulau Jawa. Jurusan Biologi FMIPA UNS, Surakarta.

Soerjani M, Jahja A, Koostermans GH, Tjitrosoepomo G (1987) Weeds of rice in Indonesia. Balai Pustaka, Jakarta.

Soeryowinoto SM (1997) Flora eksotik tanaman hias berbunga. Kanisius, Yogyakarta.

Sohmer SH (1990) Elements of Pacific phytodiversity. In Baas P (ed) The plant diversity of Malesia. Kluwer, Dordrecht.

Steenis CGGJ van (1954) Flora Malesiana Seris I. Spermatophyta. Noordhoff-Kolff NV, Djakarta.

Stuessy TF, Crawford D, Carera CM (1998) Isolating mechanism perm of the Juan Fernandez Island. In: Stuessy TF, Ono M (eds) Evolution and speciation of island plants. Cambridge University Press, London.

Stuessy TF (1990) Plant taxonomy, the systematic evaluation of comparative data. Columbia University Press, New York.

Subali B (1990) Rancangan percobaan dan analisis statistika. Jurusan Pendidikan Biologi, FPMIPA IKIP, Yogyakarta.

Sukristijono S (1990) The secondary forest of Tanah Grogot, East Kalimantan Indonesia. In: Baas P (ed) The plant diversity of Malesia. Kluwer, Dordrecht.

Sunarto H (1991) Praktikum ekologi tumbuhan, petunjuk untuk pelatihan dosen LPTK. Universitas Gadjah Mada, Yogyakarta.

Tjitrosoepomo G (1994) Taksonomi tumbuhan. Gadjah Mada University Press, Yogyakarta.

Valeton T (1918) New notes on the Zingiberaceae of Java and Malaya. Curcuma. Bull Jard Bot Buitenzorg Ser 2 (27): 1-81.

Vane-Wright RI (1992a) Systematics and diversity. In: Groombridge B (ed) Global biodiversity: status of the earth's living resources. Chapman and Hall, London.

Vane-Wright RI (1992b) Systematics and the global biodiversity strategy. Antenna 16: 49-56

Whitmore TC, Sayer JA (1994) Tropical deforestation and species extinction. Chapman and Hall, London. 